\title{
The immunology of mitral valve stenosis
}

This article was published in the following Dove Press journal:

International Journal of Interferon, Cytokine and Mediator Research

10 January 2011

Number of times this article has been viewed

\section{Rosa T Artola \\ Christos G Mihos \\ Orlando Santana}

Columbia University Division of Cardiology at Mount Sinai Heart Institute, Miami Beach, FL, USA
Correspondence: Orlando Santana Echocardiography Laboratory, Mount Sinai Heart Institute, 4300 Alton Road, Miami Beach, FL 33I40, USA

$\mathrm{Tel}+\mathrm{I} 3056742168$

Fax +I 3056742368

Email osantana@msmc.com
Abstract: Although the prevalence of rheumatic heart disease (RHD) has rapidly subsided over the last several decades in the United States, it still remains a serious cardiovascular disorder across the world, particularly in developing nations. Chronic autoimmune inflammation of the cardiac valves can result in mitral stenosis, increasing the risk of morbidity, mortality, and long-term sequelae in these patients. Researchers have begun to unravel the mysteries behind the development of RHD in the setting of chronic autoimmune inflammatory reactions and the roles genetic predisposition, antibody- and T-cell-mediated molecular mimicry, and cytokine proinflammatory responses play. In this article, the immunologic pathogenesis of RHD and its effects on the mitral valve are reviewed.

Keywords: mitral stenosis, rheumatic heart disease, inflammation, cytokines

\section{Introduction}

Rheumatic fever (RF), a sequela of untreated pharyngeal infection by group A streptococcus (GAS), has long been established as a common etiology of valvular heart disease. Once considered the primary culprit of acquired heart disease in children in the United States, the routine use of antibiotics and improved hygiene have decreased the rates of RF in the United States to $2-14.8$ cases per $100,000,{ }^{1}$ while the rates in developing countries are cited as high as 50 cases per 100,000. ${ }^{2}$ Epidemiological data suggest the existence of 15.6 million cases worldwide, with 282,000 new cases and 233,000 deaths each year. ${ }^{3}$ However, the true incidence is believed to be much higher, as epidemiological data from developing countries are believed to be average at best.

According to the Jones criteria, initially established in 1944 for use in the diagnosis of acute RF, carditis, polyarthritis, chorea, subcutaneous nodules, and erythema marginatum are the five initial 'major' clinical manifestations. ${ }^{2}$ Cardiac involvement first presents as a pancarditis, affecting the endocardium, myocardium, epicardium, and pericardium, respectively, with patients most commonly presenting with chest discomfort or pleuritic pain. Conversely, valvular dysfunction is a smoldering process, as evidenced by studies that suggest systematic echocardiographic screening reveals up to a 10-fold greater prevalence of rheumatic heart disease (RHD) compared with clinical screening alone. ${ }^{4}$ The most commonly encountered valvulopathy is mitral stenosis, ${ }^{5-7}$ a late complication resulting from chronic autoimmune valvular inflammation, leaflet thickening, and calcification, which ultimately leads to alteration of valvular structure and function. Patients with severe disease are at high risk of developing atrial fibrillation, pulmonary hypertension, and pulmonary edema. 
The underlying mechanisms involved in the development of poststreptococcal RHD and mitral stenosis are complex. There are numerous factors involved, including genetic predisposition, antibody- and T-cell-mediated molecular mimicry, and cytokine proinflammatory response, all contributing to the chronic inflammatory nature of the disease. In this article, the immunologic pathogenesis of RHD and the effects exerted on the structure and function of the mitral valve, as well as the role of antibiotics in the treatment and prevention of RF are reviewed.

\section{Genetic predisposition}

The hypothesis that individual and familial genetic factors play a role in the development and severity of RF and carditis is over a century old. ${ }^{8}$ Although many of the molecular mechanisms are incompletely understood, researchers have identified several genetic molecular variations that are linked to the autoimmune reactions seen in the disease process (Table 1).

The human leukocyte antigen (HLA) system, also known as the major histocompatibility complex (MHC), is comprised of class I and class II molecules, which are involved in alloimmune and autoimmune processes, with class II molecules implicated in the development of RHD. ${ }^{9}$ Found on B cells, macrophages, and several other antigen-presenting cells (APC), these molecules present 'exogenous' antigens to T-helper cells, ultimately leading to the production of antibodies. Several different HLA alleles, in particular HLA-DR7, have been associated with RHD and the development of valvular lesions. ${ }^{10-14}$ By furthering the recognition of streptococcal peptides through the HLA system, the presence of these alleles likely enhances autoimmune inflammatory processes and amplifies disease severity.

Tumor necrosis factor $\alpha$ (TNF- $\alpha)$ is an acute phase cytokine involved in a myriad of inflammatory processes, including initiation of cytokine cascades and recruitment of macrophages and neutrophils to sites of inflammation through chemoattractant properties. Located on chromosome 6 between genes for HLA-B and HLA-DR7, TNF- $\alpha$ has been linked to the development of RHD, particularly alleles $-308 \mathrm{~A}$ and $-238 \mathrm{~A} .{ }^{15-18}$ This most likely occurs via a phenomenon known as linkage disequilibrium, where the combination of specific HLA and TNF- $\alpha$ alleles occurs and are expressed more frequently in RHD patients than would be expected from random haplotype formation. This abnormal regulation of TNF- $\alpha$ production is theorized to be partly responsible for the aggressive nature of RHD.

Another protein that has been associated with increased risk of rheumatic carditis is mannose-binding lectin (MBL), ${ }^{19}$ a pivotal factor in innate immunity. By binding to carbohydrates on pathogen surfaces, the MBL pathway activates the complement cascade, ultimately leading to the recruitment of inflammatory cells and opsonization and destruction of pathogens. Patients with RHD and mitral stenosis have been shown to have an increased incidence of the MBL ' $A$ ' allele, which results in higher levels of MBL production, as opposed to the ' $\mathrm{O}$ ' allele, which yields lower levels..$^{20,21}$ The end result is an exaggerated complement activation that likely leads to greater valve inflammation and damage.

Functioning as pattern recognition molecules, toll-like receptors (TLR) are cell surface proteins that recognize microbial structures such as lipoproteins, peptidoglycans, and lipoteichoic acid, generating signals that ultimately result in the activation of innate immune responses. It has been postulated that in patients with RF, altered TLR function may contribute to the inflammatory processes that lead to RHD. Researchers have found that a polymorphism of TLR2 at position 753 , in which arginine is replaced by glutamine, and three single-nucleotide polymorphisms in TLR5 gene

Table I Established genetic risk factors for RHD

\begin{tabular}{|c|c|c|}
\hline & Function & Genetic variation in RHD \\
\hline HLA & $\begin{array}{l}\text { Present 'exogenous' antigens to T-helper cells, ultimately } \\
\text { leading to the production of antibodies }\end{array}$ & $\begin{array}{l}\text { HLA-DR7 allele associated with RHD and } \\
\text { development of valvular lesions }{ }^{10-14}\end{array}$ \\
\hline TNF- $\alpha$ & $\begin{array}{l}\text { Acute phase cytokine involved in initiation of cytokine } \\
\text { cascades and recruitment of macrophages and neutrophils } \\
\text { to sites of inflammation through chemoattractant properties }\end{array}$ & $\begin{array}{l}\text { Alleles }-308 \mathrm{~A} \text { and }-238 \mathrm{~A} \text { associated with the } \\
\text { development of RHD and are overexpressed via } \\
\text { linkage disequilibrium with HLA-DR7 allele }{ }^{15-18}\end{array}$ \\
\hline MBL & $\begin{array}{l}\text { Activates the lectin-complement cascade, leading to the } \\
\text { recruitment of inflammatory cells and opsonization and } \\
\text { destruction of pathogens }\end{array}$ & $\begin{array}{l}\text { Increased incidence of the MBL 'A' allele, resulting } \\
\text { in higher levels of } M B L \text { production' }{ }^{20,21}\end{array}$ \\
\hline TLR & $\begin{array}{l}\text { Pattern-recognition cell surface proteins that recognize } \\
\text { microbial structures and activate innate immune responses }\end{array}$ & $\begin{array}{l}\text { Polymorphism of TLR2 at position } 753 \text { and three } \\
\text { single-nucleotide polymorphisms in TLR5 gene }{ }^{22,23}\end{array}$ \\
\hline
\end{tabular}

Abbreviations: RHD, rheumatic heart disease; HLA, human leukocyte antigen; TNF- $\alpha$, tumor necrosis factor $\alpha$; MBL, mannose-binding lectin; TLR, toll-like receptor. 
are strongly associated with the pathogenesis of acute RF and may indeed intensify the inflammatory reactions taking place. $^{22,23}$

Furthermore, researchers are in the early stages of understanding several other genes associated with enhanced RHD progression. These include polymorphisms of ficolin-2, a pattern-recognition protein important to the lectin complement pathway; ${ }^{24} \mathrm{C}-509 \mathrm{~T}$ and T869C polymorphisms of transforming growth factor $\beta-1$, a cytokine secreted by most immune cells that controls their differentiation, proliferation, and state of function, ${ }^{25,26}$ and polymorphism of interleukin 1 (IL-1) receptor antagonist, a cytokine that normally modulates IL-1-related inflammatory processes. ${ }^{27}$ Further studies are imperative, as knowledge about genetic predictors can advance screening and therapeutic options for RHD patients.

\section{Molecular mimicry}

Molecular mimicry, defined as the sharing of epitopes between foreign and self-peptides that can trigger crossactivation of the host's immune system, is crucial to the pathogenesis of RHD.

Three types of mimicry have been defined as mechanisms for cross-reactivity mediated by anticardiac antibodies: 1) identical amino acid sequences, 2) homologous but nonidentical amino acid sequences, and 3) epitopes on distinctive molecules, including carbohydrates, gangliosides, and DNA. ${ }^{28,29}$ By these mechanisms, antistreptococcal monoclonal antibodies (mAbs) have been shown to recognize and cross-react with streptococcal $M$ protein and cardiac myosin, a contractile protein vital to proper cardiac function. ${ }^{30,31}$ Significant mimicry between antistreptococcal $\mathrm{M}$ protein $\mathrm{mAb}$ and cardiac myosin epitopes has been shown to trigger myocarditis and valvulitis in susceptible animal models,${ }^{32}$ and mimicry also exists with other $\alpha$-helical coiled proteins found in the heart and cardiac valves, including vimentin, keratin, and laminin, ${ }^{30,33,34}$ important peptides that contribute to the extracellular matrix of human cardiac tissue. Additionally, studies have shown that mAbs also bind $N$-acetyl-glucosamine, the GAS dominant carbohydrate. These antibodies cross-react with peptides that in turn interact with lectins, ${ }^{35}$ theoretically triggering an immune response via the lectin-complement pathway. Taken as a whole, these complex interactions can lead to contractile and valvular cardiac decompensation, triggering further inflammatory reactions within the valvular structures.

In addition to antibody-mediated interactions, studies involving T-cell clones from patients with RHD have demonstrated the cross-reactivity of streptococcal M peptides with valvular proteins and cardiac myosin by T-cell-mediated molecular mimicry. T-cell clones from heart lesions of RHD patients have shown the ability to simultaneously recognize heart tissue-derived proteins and streptococcal M5 protein peptides,${ }^{36}$ in particular, immunodominant peptide residues 81-96 and 83-103, ${ }^{10,37}$ epitopes also recognized by peripheral T lymphocytes in the context of HLA-DR7. ${ }^{38}$ Furthermore, analysis of the N-terminal portion of the M5 protein and cardiac myosin has yielded three distinct cardiac myosin epitopes targeted by molecular mimicry in the S2 and light meromyosin regions. ${ }^{39,40}$

Finally, heart-infiltrating and peripheral T cells have also been shown to recognize numerous valvular autoantigens, including protein disulfide isomerase family A member 3 (PDIA3), heat shock $70 \mathrm{kDa}$ protein 5 (HSPA5), and vimentin. ${ }^{41}$ Although the exact role of PDIA3 remains unclear, HSPA5 is believed to participate in $\mathrm{Ca}^{2+}$ sequestration, as well as folding and assembly of proteins and rearrangement of misfolded proteins within the endoplasmic reticulum, and acts as an antiapoptosis protein. ${ }^{42,43}$ The ability of $\mathrm{T}$ cells to recognize HSPA5 suggests that exposure occurs as a result of inflammatory tissue damage, with loss of protein function likely contributing to further valvular dysfunction.

\section{Pathogenesis of valvular disease}

Untreated pharyngeal bacterial infection by group A Streptococcus pyogenes, a facultative Gram-positive coccus, is the inciting factor in RHD (Table 2). The bacterial cell wall consists of a peptidoglycan backbone with integral lipoteichoic acid components that facilitate adherence to host pharyngeal epithelial cells and also possess the ability to activate the alternative complement pathway. ${ }^{44}$ Bacterial adherence is enhanced by fibronectin-binding protein $\mathrm{F}$, which allows interaction between GAS and epithelial cell integrins, with cell-surface receptors also playing a pivotal role in cell signaling. ${ }^{45}$ In addition, $M$ proteins contribute to GAS adherence via the binding of human endothelial cellsurface glycosaminoglycans, as well as the complement control protein factor $\mathrm{H}$, which allows the bacteria to evade opsonization. ${ }^{46,47}$

However, the most important factor in the virulence of GAS is the bacterial capsule. The capsular polysaccharide is composed of hyaluronic acid, a high molecular weight polysaccharide essential to GAS virulence, which is structurally identical to mammalian hyaluronic acid found on cell surfaces, connective tissue, and extracellular matrix. ${ }^{48}$ 
Table 2 Pathogenesis of valvular disease

Untreated $\beta$-hemolytic GAS pharyngeal infection

$\Downarrow$

Innate immune responses (macrophage, NK cell, complement pathway activation), activation of acute phase proteins (interleukins, TNF- $\alpha, \mathrm{MBL}$ ), and production of INF- $\gamma$

$\Downarrow$

Adaptive immune responses (B lymphocytes, $\mathrm{T}$ lymphocytes, HLA molecules)

$\Downarrow$

T-cell- and antibody-mediated molecular mimicry between streptococcal $M$ protein and cardiac myosin and valvular proteins $\Downarrow$

Deposition of Aschoff bodies are along the coapting portions of the leaflets with continued production and secretion of proinflammatory cytokines

$\Downarrow$

Deposition of fibrin on the valvular cusps, leading to fusion of the leaflet commissures, shortening of the chordae tendinae, and alteration of the native valvular morphology

$\Downarrow$

Leaflet thickening and valvular calcification

$\Downarrow$

Epitope spreading leading to continued T-helper-I cell granulomatous valvular response

$\Downarrow$

Mitral stenosis

Abbreviations: GAS, group A streptococcus; NK cell, natural killer cell; TNF- $\alpha$, tumor necrosis factor $\alpha$; MBL, mannose-binding lectin; INF- $\gamma$, interferon- $\gamma$, HLA, human leukocyte antigen.

Mammalian hyaluronic acid binds to CD44, a cell-surface glycoprotein involved in human cell-cell and cell-matrix interactions, including lymphocyte activation, recircling, and homing. Research has demonstrated, in vitro and in vivo, that attachment of GAS to pharyngeal epithelial cells occurs through the binding of the microbial hyaluronic acid capsular polysaccharide to human CD44 antigen, ${ }^{49}$ thus establishing infection and triggering lymphocyte activation, as well as providing resistance against host phagocytosis.

Once infection has occurred, innate and adaptive immune responses unfold via several intertwining mechanisms. Inflammation triggers the production of several acute phase reactants pivotal to the development of RHD, ${ }^{19,50,51}$ most importantly: 1) MBL, which binds to $N$-acetyl- $\beta$-D-glucosamine, a streptococcal cell wall carbohydrate, activating the complementlectin pathway; 2) IL-1, which increases the expression of adhesion factors on endothelial cells to enable the transmigration of leukocytes and enhancement of the host inflammatory response; 3) IL-6, which functions in both innate and adaptive immunity by stimulating the synthesis of acute phase proteins, neutrophils, and B lymphocytes; and 4) TNF- $\alpha$, which serves to recruit and activate monocytes and neutrophils at the site of infection. Furthermore, natural killer cells produce interferon- $\gamma$, a principal macrophage-activating cytokine that stimulates expression of class I and class II MHC molecules on APC and promotes differentiation of CD4+ T cells to T-helper-1 cells. T-helper-1 cells in turn secrete interferon- $\gamma$ themselves and produce IL-2, which functions as a growth factor for antigen-stimulated $\mathrm{T}$ cells and $\mathrm{B}$ cells, increases cytokine synthesis, and promotes proliferation of natural killer cells. RHD patients appear to have an increased production of T-helper cells, resulting in a greater amount of IL-2 in systemic circulation. ${ }^{52}$ Finally, newly described T-helper-17 cells have been shown to produce IL-17, which is believed to upregulate the production of other proinflammatory cytokines and chemokines. Increased expression of IL-17 in peripheral T cells of RHD patients has been observed, ${ }^{53}$ leading to the conclusion that these cells may also contribute to the inflammatory reactions in rheumatic heart lesions.

The activation of B lymphocytes results in the production of antibodies and subsequent cross-reactive molecular mimicry between the streptococcal immunodominant carbohydrate antigen $\mathrm{N}$-acetyl-glucosamine and cardiac myosin, valvular endothelium and laminin. ${ }^{33}$ Antibodies also upregulate the expression of vascular cell adhesion molecule-1, a protein that mediates the binding of lymphocytes and monocytes to vascular endothelium, allowing adhesion and infiltration of T cells through the endothelium and endocardium into the valve. ${ }^{54}$ Although cardiac valves have been labeled as avascular structures, recent studies have demonstrated that rheumatic valves have severe upregulation and downregulation of proangiogenic and antiangiogenic factors, respectively. RHD patients have been shown to have decreased levels of chondromodulin-I and tenomodulin, antiangiogenic proteins first expressed in the cardiac valves and chordae tendineae during embryogenesis. ${ }^{55-57}$ Conversely, increased levels of periostin, a proangiogenic protein also expressed in embryonic cardiac valves, has been recently described in RHD patients. Periostin also upregulates the production of matrix metalloproteinase, an endopeptidase responsible for angiogenesis and tissue remodeling. ${ }^{58}$

As APC express HLA class II molecules that present streptococcal peptides toi helper T cells, valvular inflammation and damage begins to occur. Over time, the mitral valve apparatus becomes diseased and tiny granulomatous nodules 
known as Aschoff bodies are deposited along the coapting portions of the leaflets. These inflammatory structures contain macrophages and $\mathrm{T}$ cells specific for streptococcal $\mathrm{M}$ protein, and continued production and secretion of proinflammatory cytokines takes place. ${ }^{59}$ Inflammation ensues and eventual deposition of fibrin on the valvular cusps occurs, leading to fusion of the leaflet commissures, shortening of the chordae tendineae, and alteration of the native valvular morphology ${ }^{60,61}$ Over the years, leaflet thickening and calcification occur, ultimately leading to mitral stenosis. Although long-term stress secondary to turbulent flow through the deformed valve plays a role, calcification and scarring of the valve are also likely caused by a chronic, subclinical form of inflammation, suggested by the increased expression of osteoblast markers and neoangiogenesis seen in RHD patients. ${ }^{62}$ Additionally, although mononuclear cells secreting the regulatory cytokine IL-4 have been found in the myocardium, few cells have been isolated in the cardiac valves. The lower expression of IL-4 in the valves of RHD patients may contribute to the progression of cell-mediated valvular damage. ${ }^{59}$

Ultimately, once valvular disease has become chronic, proteins integral in maintaining proper anatomical function such as vimentin, laminin, collagen, and others are presented to the immune system, and epitope spreading is predicted to occur. ${ }^{29}$ Through this mechanism, autoimmune reactions against a self-antigen lead to the release of other antigens and associated lymphocytes, resulting in an enhanced, chronic disease process. It is theorized that these immune reactions continue to promote a T-helper-1 cell granulomatous response in the mitral valve, leading to additional scarring and further functional decompensation. ${ }^{59}$

\section{Treatment and prevention of RF}

Primary prevention of acute RF and RHD can be effectively accomplished with proper diagnosis and treatment of GAS tonsillopharyngitis with penicillin. According to the American Heart Association, untreated patients who develop acute RF require antibiotic treatment with the goal of GAS carriage eradication, regardless of whether concomitant pharyngeal infection is present. ${ }^{63}$ This is accomplished via treatment regimens outlined for GAS pharyngeal infections, with oral penicillin $\mathrm{V}$ or intramuscular penicillin $\mathrm{G}$ as the drugs of choice. Diagnosis is typically confirmed by a rising antistreptolysin titer, as well as antideoxyribonuclease B, antistreptokinase, and antihyaluronidase antibodies, while acute phase reactants such as C-reactive protein and erythrocyte sedimentation rate are used in monitoring the response to treatment ${ }^{64} \mathrm{C}$-reactive protein levels are particularly applicable, as normalized levels are typically observed within days of inflammatory resolution, whereas erythrocyte sedimentation rate can remain elevated for several months.

In patients with a prior episode of RF, secondary prevention is critically important. Recurrent pharyngeal GAS infection can trigger a severely exaggerated immune response in these patients, and studies have shown that recurrent RF is associated with a higher incidence of carditis and mortality, highlighting the need for preventative medicine in this population. ${ }^{65,66}$ The duration of prophylactic antibiotic administration is dependent on several factors, including patient age, risk of re-exposure to GAS, number of prior episodes, length of time since prior infection, and most importantly, the presence of valvular heart disease. In general, prophylaxis is continued until the age of 21 years if there is no prior cardiac involvement; however, in the setting of valvular disease, treatment is continued until the age of 40 years, and in some instances, is recommended to be continued lifelong. ${ }^{63}$ Long-acting benzathine penicillin $\mathrm{G}$, injected intramuscularly every 4 weeks, has been established as the standard of care, and data suggests that strict adherence and close follow-up reduces morbidity, reinfection rates, and long-term sequelae. ${ }^{67,68}$

Finally, up to $25 \%$ of asymptomatic individuals may be carriers of GAS. ${ }^{69}$ Although routine screening of the general public is not practiced, the Infectious Disease Society of America recommends streptococcal rapid antigen detection tests for patients with a history of RF or acute pharyngitis during outbreaks of RF or poststreptococcal glomerulonephritis, as well as those residing in closed communities or in the setting of spread amongst household members. ${ }^{70}$ A full course of antibiotic treatment is suggested if results are positive regardless of the presence of symptoms, as colonization has been linked to higher rates of disease and sequelae, ${ }^{71}$ and studies have shown that at least one-third of reported cases of acute RF occur in asymptomatic patients. $^{72}$

\section{Conclusion}

The immunology and pathogenesis of RF and rheumatic carditis demonstrate the interplay of innate and adaptive immunity, as well as humoral and cellular immune reactions. Although researchers have made great strides in elucidating many of these complex mechanisms, the progression of RHD from group A streptococcal pharyngeal infection to 
mitral stenosis remains incompletely understood. Primary prevention of RF should be the goal of all clinicians and requires diligent application of clinical parameters and a prompt diagnosis of streptococcal tonsillopharyngitis, primarily in the pediatric population, where pharyngeal GAS infection establishes a nadir for RHD and subsequent mitral stenosis. Furthermore, proper school or community-based treatment programs have proven to reduce the incidence of RF and thus valvular disease, and should be a cornerstone in public health policy. Thus, future research on the genetic, molecular, and clinical levels is of utmost importance, as RHD and mitral stenosis remain significant worldwide diseases with serious sequelae.

\section{Acknowledgment}

This study did not receive any financial support.

\section{Disclosure}

The authors report no conflicts of interest in this work.

\section{References}

1. Miyake CY, Gauvreau K, Tani LY, Sundel RP, Newburger JW. Characteristics of children discharged from hospitals in the United States in 2000 with the diagnosis of acute rheumatic fever. Pediatrics. 2007;120(3):503-508.

2. Special Writing Group of the Committee on Rheumatic Fever, Endocarditis, and Kawasaki Disease of the Council on Cardiovascular Disease in the Young of the American Heart Association. Guidelines for the diagnosis of rheumatic fever: Jones criteria, 1992 update. JAMA. 1992;268(15):2069-2073.

3. Carapetis JR, Steer AC, Mulholland EK, Weber M. The global burden of group A streptococcal diseases. Lancet Infect Dis. 2005;5(11): 685-694.

4. Marijon E, Ou P, Celermajer DS, et al. Prevalence of rheumatic heart disease detected by echocardiographic screening. $N$ Engl J Med. 2007; 357(5):470-476.

5. Waller B, Howard J, Fess S. General concepts in the morphologic assessment of operatively excised cardiac valves-Part I. Clin Cardiol. 1994;17(1):41-46.

6. Hanson TP, Edwards BS, Edwards JE. Pathology of surgically excised mitral valves. One hundred consecutive cases. Arch Pathol Lab Med. 1985;109(9):823-828.

7. Olson LJ, Subramanian R, Ackermann DM, Orszulak TA, Edwards WD. Surgical pathology of the mitral valve: a study of 712 cases spanning 21 years. Mayo Clin Proc. 1987;62(1):22-34.

8. Cheadle WB. Harvean lectures on the various manifestations of the rheumatic state as exemplified in childhood and early life. Lancet. $1889 ; 1: 821-832$.

9. Ayoub EM, Barrett DJ, Maclaren NK, Krischer JP. Association of class II human histocompatibility leukocyte antigens with rheumatic fever. J Clin Invest. 1986;77(6):2019-2026.

10. Guilherme L, Weidebach W, Kiss MH, Snitcowsky R, Kalil J. Association of human leukocyte class II antigens with rheumatic fever or rheumatic heart disease in a Brazilian population. Circulation. 1991; 83(6):1995-1998.

11. Ozkan M, Carin M, Sönmez G, Senocak M, Ozdemir M, Yakut C. HLA antigens in Turkish race with rheumatic heart disease. Circulation. 1993;87(6):1974-1978.
12. Guédez Y, Kotby A, El-Demellawy M, et al. HLA class II associations with rheumatic heart disease are more evident and consistent among clinically homogeneous patients. Circulation. 1999;99(21):2784-2790.

13. Visentainer JE, Pereira FC, Dalalio MM, Tsuneto LT, Donadio PR, Moliterno RA. Association of HLA-DR7 with rheumatic fever in the Brazilian population. $J$ Rheumatol. 2000;27(6):1518-1520.

14. Stanevicha V, Eglite J, Sochnevs A, Gardovska D, Zavadska D, Shantere R. HLA class II associations with rheumatic heart disease among clinically homogeneous patients in children in Latvia. Arthritis Res Ther. 2003;5(6):R340-R346.

15. Hernández-Pacheco G, Flores-Domínguez C, Rodríguez-Pérez JM, et al. Tumor necrosis factor-alpha promoter polymorphisms in Mexican patients with rheumatic heart disease. J Autoimmun. 2003; 21(1):59-63.

16. Sallakci N, Akcurin G, Köksoy S, et al. TNF-alpha G-308A polymorphism is associated with rheumatic fever and correlates with increased TNF-alpha production. J Autoimmun. 2005;25(2):150-154.

17. Ramasawmy R, Faé KC, Spina G, et al. Association of polymorphisms within the promoter region of the tumor necrosis factor-alpha with clinical outcomes of rheumatic fever. Mol Immunol. 2007;44(8): 1873-1878.

18. Settin A, Abdel-Hady H, El-Baz R, Saber I. Gene polymorphisms of TNF-alpha(-308), IL-10(-1082), IL-6(-174), and IL-1Ra(VNTR) related to susceptibility and severity of rheumatic heart disease. Pediatr Cardiol. 2007;28(5):363-371.

19. Schafranski MD, Stier A, Nisihara R, Messias-Reason IJ. Significantly increased levels of mannose-binding lectin (MBL) in rheumatic heart disease: a beneficial role for MBL deficiency. Clin Exp Immunol. 2004; 138(3):521-525.

20. Messias Reason IJ, Schafranski MD, Jensenius JC, Steffensen R. The association between mannose-binding lectin gene polymorphism and rheumatic heart disease. Hum Immunol. 2006;67(12):991-998.

21. Schafranski MD, Pereira Ferrari L, Scherner D, Torres R, Jensenius JC, de Messias-Reason IJ. High-producing MBL2 genotypes increase the risk of acute and chronic carditis in patients with history of rheumatic fever. Mol Immunol. 2008;45(14):3827-3831.

22. Berdeli A, Celik HA, Ozyürek R, Dogrusoz B, Aydin HH. TLR-2 gene Arg753Gln polymorphism is strongly associated with acute rheumatic fever in children. J Mol Med. 2005;83(7):535-541.

23. Zhu L, Zou LJ, Hua R, Li B. Association of single-nucleotide polymorphisms in toll-like receptor 5 gene with rheumatic heart disease in Chinese Han population. Int J Cardiol. 2010;145(1):129-130.

24. Messias-Reason IJ, Schafranski MD, Kremsner PG, Kun JF. Ficolin 2 (FCN2) functional polymorphisms and the risk of rheumatic fever and rheumatic heart disease. Clin Exp Immunol. 2009;157(3): 395-399.

25. Chou HT, Chen CH, Tsai CH, Tsai FJ. Association between transforming growth factor-beta1 gene C-509T and T869C polymorphisms and rheumatic heart disease. Am Heart J. 2004;148(1):181-186.

26. Kamal H, Hussein G, Hassoba H, Mosaad N, Gad A, Ismail M. Transforming growth factor-beta1 gene C-509T and T869C polymorphisms as possible risk factors in rheumatic heart disease in Egypt. Acta Cardiol. 2010;65(2):177-183.

27. Azevedo PM, Bauer R, Caparbo Vde F, Silva CA, Bonfá E, Pereira RM. Interleukin-1 receptor antagonist gene (IL1RN) polymorphism possibly associated to severity of rheumatic carditis in a Brazilian cohort. Cytokine. 2010;49(1):109-113.

28. Cunningham MW. Pathogenesis of group A streptococcal infections. Clin Microbiol Rev. 2000;13(3):470-511.

29. Guilherme L, Kalil J, Cunningham M. Molecular mimicry in the autoimmune pathogenesis of rheumatic heart disease. Autoimmunity. 2006;39(1):31-39.

30. Shikhman AR, Cunningham MW. Immunological mimicry between $\mathrm{N}$-acetyl-beta-D-glucosamine and cytokeratin peptides. Evidence for a microbially driven anti-keratin antibody response. J Immunol. 1994;152(9):4375-4387. 
31. Cunningham MW, Hall NK, Krisher KK, Spanier AM. A study of anti-group A streptococcal monoclonal antibodies cross-reactive with myosin. J Immunol. 1986;136(1):293-298.

32. Galvin JE, Hemric ME, Kosanke SD, Factor SM, Quinn A, Cunningham MW. Induction of myocarditis and valvulitis in Lewis rats by different epitopes of cardiac myosin and its implications in rheumatic carditis. Am J Pathol. 2002;160(1):297-306.

33. Galvin JE, Hemric ME, Ward K, Cunningham MW. Cytotoxic mAB from rheumatic carditis recognizes heart valves and laminin. $J$ Clin Invest. 2000;106(2):217-224.

34. Guliza JM, Cunningham MW, McManus BM. Anti-streptococcal monoclonal antibodies recognize multiple epitopes in human heart valves: cardiac myosin, vimentin and elastin as potential valvular autoantigens. In: Orefici G, editor. New Perspectives on Streptococci and Streptococcal Infections. Proceedings of the XI Lancefield International Symposium (Zentralbl Bakteriol Suppl 22). New York. NY: Gustav-Fischer-Verlag; 1992:267-269.

35. Shikhman AR, Greenspan NS, Cunningham MW. Cytokeratin peptide SFGSGFGGGY mimics N-acetyl-beta-D-glucosamine in reaction with antibodies and lectins, and induces in vivo anti-carbohydrate antibody response. J Immunol. 1994;153(12):5593-5606.

36. Guilherme L, Cunha-Neto E, Coelho V, et al. Human heart-infiltrating T-cell clones from rheumatic heart disease patients recognize both streptococcal and cardiac proteins. Circulation. 1995;92(3): 415-420.

37. Faé KC, da Silva DD, Oshiro SE, et al. Mimicry in recognition of cardiac myosin peptides by heart-intralesional $\mathrm{T}$ cell clones from rheumatic heart disease. J Immunol. 2006;176(9):5662-5670.

38. Guilherme L, Oshiro SE, Faé KC, et al. T-cell reactivity against streptococcal antigens in the periphery mirrors reactivity of heart-infiltrating $\mathrm{T}$ lymphocytes in rheumatic heart disease patients. Infect Immun. 2001;69(9):5345-5351.

39. Cunningham MW. T cell mimicry in inflammatory heart disease. Mol Immunol. 2004;40(14-15):1121-1127.

40. Ellis NM, Li Y, Hildebrand W, Fischetti VA, Cunningham MW. T cell mimicry and epitope specificity of cross-reactive $\mathrm{T}$ cell clones from rheumatic heart disease. J Immunol. 2005;175(8):5448-5456.

41. Faé KC, Diefenbach da Silva D, Bilate AMB, et al. PDIA3, HSPA5 and vimentin, proteins identified by 2-DE in the valvular tissue, are the target antigens of peripheral and heart infiltrating $\mathrm{T}$ cells from chronic rheumatic heart disease patients. J Autoimmun. 2008;31(2):136-141.

42. Mayer M, Kies U, Kammermeier R, Buchner J. BiP and PDI cooperate in the oxidative folding of antibodies in vitro. $J$ Biol Chem. 2000;275(38):29421-29425.

43. Lièvremont JP, Rizzuto R, Hendershot L, Meldolesi J. BiP, a major chaperone protein of the endoplasmic reticulum lumen, plays a direct and important role in the storage of the rapidly exchanging pool of $\mathrm{Ca}^{+}$. J Biol Chem. 1997;272(49):30873-30879.

44. Hasty DL, Ofek I, Courtney HS, Doyle RJ. Multiple adhesins of streptococci. Infect Immun. 1992;60(6):2147-2152.

45. Natanson S, Sela S, Moses AE, Musser JM, Caparon MG, Hanski E. Distribution of fibronectin-binding proteins among group A streptococci of different M types. J Infect Dis. 1995;171(4):871-878.

46. Frick IM, Schmidtchen A, Sjöbring U. Interactions between M proteins of Streptococcus pyogenes and glycosaminoglycans promote bacterial adhesion to host cells. Eur J Biochem. 2003;270(10): 2303-2311.

47. Fischetti VA, Horstmann RD, Pancholi V. Location of the complement factor $\mathrm{H}$ binding site on streptococcal M6 protein. Infect Immun 1995;63(1):149-153.

48. Sandson J, Hamerman D, Janis R, Rojkind M. Immunologic and chemical similarities between the streptococcus and human connective tissue. Trans Assoc Am Physicians. 1968;81:249-257.

49. Cywes C, Stamenkovic I, Wessels MR. CD44 as a receptor for colonization of the pharynx by group A Streptococcus. $J$ Clin Invest. 2000;106(8):995-1002.
50. Narin N, Kütükçüler N, Ozyürek R, Bakiler AR, Parlar A, Arcasoy M. Lymphocyte subsets and plasma IL-1 alpha, IL-2, and TNF-alpha concentrations in acute rheumatic fever and chronic rheumatic heart disease. Clin Immunol Immunopathol. 1995;77(2):172-176.

51. Yegin O, Coskun M, Ertug H. Cytokines in acute rheumatic fever. Eur J Pediatr. 1997;156(1):25-29.

52. Morris K, Mohan C, Wahi PL, Anand IS, Ganguly NK. Enhancement of IL-1, IL-2 production and IL-2 receptor generation in patients with acute rheumatic fever and active rheumatic heart disease: a prospective study. Clin Exp Immunol. 1993;91(3):429-436.

53. Guilherme L, Kalil J. Rheumatic fever and rheumatic heart disease: cellular mechanisms leading autoimmune reactivity and disease. J Clin Immunol. 2010;30(1):17-23.

54. Cunningham MW. Autoimmunity and molecular mimicry in the pathogenesis of post-streptococcal heart disease. Front Biosci. 2003;8:s533-s543.

55. Mariscalco G, Lorusso R, Sessa F, et al. Imbalance between proangiogenic and anti-angiogenic factors in rheumatic and mixomatous mitral valves. Int J Cardiol. 2010 Sep 10. Epub ahead of print.

56. Yoshioka M, Yuasa S, Matsumura K, et al. Chondromodulin-I maintains cardiac valvular function by preventing angiogenesis. Nat Med. 2006;12(10):1151-1159.

57. Kimura N, Shukunami C, Hakuno D, et al. Local tenomodulin absence, angiogenesis, and matrix metalloproteinase activation are associated with the rupture of the chordae tendineae cordis. Circulation. 2008;118(17):1737-1747.

58. Hakuno D, Kimura N, Yoshioka M, et al. Periostin advances atherosclerotic and rheumatic cardiac valve degeneration by inducing angiogenesis and MMP production in humans and rodents. $J$ Clin Invest. 2010;120(7):2292-2306.

59. Guilherme L, Cury P, Demarchi LM, et al. Rheumatic heart disease: proinflammatory cytokines play a role in the progression and maintenance of valvular lesions. Am J Pathol. 2004;165(5):1583-1591.

60. Marcus RH, Sareli P, Pocock WA, Barlow JB. The spectrum of severe rheumatic mitral valve disease in a developing country. Correlations among clinical presentation, surgical pathologic findings, and hemodynamic sequelae. Ann Intern Med. 1994;120(3):177-183.

61. Selzer A, Cohn KE. Natural history of mitral stenosis: a review. Circulation. 1972;45(4):878-890.

62. Chopra P, Gulwani H. Pathology and pathogenesis of rheumatic heart disease. Indian J Pathol Microbiol. 2007;50(4):685-697.

63. Gerber MA, Baltimore RS, Eaton CB, et al. Prevention of rheumatic fever and diagnosis and treatment of acute Streptococcal pharyngitis: a scientific statement from the American Heart Association Rheumatic Fever, Endocarditis, and Kawasaki Disease Committee of the Council on Cardiovascular Disease in the Young, the Interdisciplinary Council on Functional Genomics and Translational Biology, and the Interdisciplinary Council on Quality of Care and Outcomes Research: endorsed by the American Academy of Pediatrics. Circulation. 2009;119(11):1541-1551.

64. Breda L, Nozzi M, De Sanctis S, Chiarelli F. Laboratory tests in the diagnosis and follow-up of pediatric rheumatic diseases: an update. Semin Arthritis Rheum. 2010;40(1):53-72.

65. Rayamajhi A, Sharma D, Shakya U. First-episode versus recurrent acute rheumatic fever: is it different? Pediatr Int. 2009;51(2): 269-275.

66. Kumar R, Raizada A, Aggarwal AK, Ganguly NK. A community-based rheumatic fever/rheumatic heart disease cohort: twelve-year experience. Indian Heart J. 2002;54(1):54-58.

67. Pelajo CF, Lopez-Benitez JM, Torres JM, de Oliveira SK. Adherence to secondary prophylaxis and disease recurrence in 536 Brazilian children with rheumatic fever. Pediatr Rheumatol Online J. 2010;8:22.

68. Meira ZM, Goulart EM, Colosimo EA, Mota CC. Long term follow up of rheumatic fever and predictors of severe rheumatic valvar disease in Brazilian children and adolescents. Heart. 2005;91(8): 1019-1022. 
69. Schwartz RH, Wientzen RL Jr, Pedreira F, Feroli EJ, Mella GW, Guandolo VL. Penicillin V for group A streptococcal pharyngotonsillitis. A randomized trial of seven vs ten days' therapy. JAMA. 1981;246(16):1790-1795.

70. Bisno AL, Gerber MA, Gwaltney JM Jr, Kaplan EL, Schwartz RH; Infectious Diseases Society of America. Practice guidelines for the diagnosis and management of group A streptococcal pharyngitis. Infectious Diseases Society of America. Clin Infect Dis. 2002;35(2):113-125.
71. Erdem G, Sinclair S, Marrone JR, et al. Higher rates of streptococcal colonization among children in the Pacific Rim Region correlates with higher rates of group A streptococcal disease and sequelae. Clin Microbiol Infect. 2010;16(5):452-455.

72. Dajani AS. Current status of nonsuppurative complications of group A streptococci. Pediatr Infect Dis J. 1991;10(10 Suppl):S25-S27.

\section{Publish your work in this journal}

The International Journal of Interferon, Cytokine and Mediator Research is an international, peer-reviewed, open-access, online journal. The focus of the journal is to publish original research, reports, editorials, reviews and commentaries on all aspects of interferon, cytokine and mediators of inflammation from labora- tory science to therapeutic indications and clinical studies. The manuscript management system is completely online and includes a very quick and fair peer-review system, which is all easy to use. Visit http://www.dovepress.com/testimonials.php to read real quotes from published authors.

Submit your manuscript here: http://www.dovepress.com/international-journal-of-interferon-cytokine-and-mediator-research-journal 